\title{
Investigating Interpersonal Meaning-Making in Indonesian EFL Learners' Writing: A Systemic Functional Perspective
}

\author{
*1Yasinda Kania Afsari, ${ }^{2}$ Murti Ayu Wijayanti, ${ }^{3}$ Dhafid Wahyu Utomo \\ ${ }^{1-3}$ Universitas Sultan Ageng Tirtayasa, Indonesia. \\ *Correspondence: \\ dhafid.wu@untirta.ac.id
}

Submission History:

Submitted: August 09, 2021

Revised: October 05, 2021

Accepted: October 14, 2021

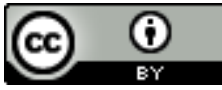

This article is licensed under a Creative Commons Attribution 4.0 International License.

\begin{abstract}
This study looks into how students create interpersonal meaning when writing analytical exposition texts. The purpose of this study is to describe the most prevalent mood kinds as well as the modality realization techniques employed in the text. To evaluate, nine texts were selected from a total of 144. The framework for analyzing the clauses of the text is based on Systemic Functional Linguistics ideas. Students employed mood types, as evidenced by the usage of subject and finite as mood elements, and predicator, adjunct, and complement as residue, according to the findings of this study. The mood element ad residue arrangement reveals the mood type they utilized. Students sought to give information in the text, as seen by the results. In terms of modality, the median modality appears more frequently in this text than the high and low modality options. It shows that the pupils are making an effort to position themselves in the text and develop a relationship with the reader. Furthermore, the students did not present any possibilities for readers to dispute their position in the text, as seen by the zero frequency of low modality. Finally, as a pedagogical implication, the problem-solving approach is appropriate for students to improve cognitive aspects in terms of communicative skills, resulting in students being able to write an effective analytical exposition text that is intended to critically discuss something from one point of view.
\end{abstract}

Keywords: interpersonal meaning, systemic functional linguistics, analytical exposition text.

\section{INTRODUCTION}

People engage through language during the communication process. Because it is a basic concept of interaction, language plays a vital part in our daily life. In any interaction, language is a crucial instrument for transmitting information, commodities, and services. According to Halliday (1994), language is a tool for creating meaning, and meaning is 
formed in context. English is utilized for worldwide communication since it is an international language. Because globalization continues to rise, the demand for professional English teachers is increasing. Language learning and teaching encompasses not just the study of grammar structure, but also the ability of pupils to perform language in a context-appropriate manner. The English Education Departments strive to meet the needs of globalization by preparing future professional teachers, especially their writing abilities. One method of communicating is through writing. People communicate not only by speaking or speech, but also through written writing (e.g., newspapers, newsletters, magazines, and academic text). They serve a similar purpose in both speech and writing: to convey a message or a notion. It is critical to choose the suitable word choice for language in a certain context in order to convey the message. The English Department's curriculum teaches students how to write in order for them to be able to convey their thoughts or messages through meaningful prose. Students must create a text to persuade others that they are entitled to receive a relevant text from the students.

However, it is rarely discussed whether or not the pupils have already created the important material. Interpersonal meaning is a tool that uses the structure of systemic functional linguistics (SFL) to analyze meaningful text and context. From the standpoint of SFL, language has both systemic and functional aspects. It emphasizes meaning as a choice in evaluating language, and it is designed to interpret how language is utilized. In his SFL theory, Halliday (1976) differentiated three metafunctions to examine language. The interpersonal metafunction is one of the three metafunctions that learns how language is used to produce meaning in maintaining social relationships. The writer's position in the text can also be analyzed using interpersonal metafunction. Language in the text becomes an important aspect to study from the perspective of interpersonal meaning.

Most studies on interpersonal meaning analysis have focused on newspapers, such as (Ayoola \& Olusanya, 2013; Sukma \& Utomo, 2017), newsletters, such as (Yuliana \& Imperiani, 2017), media text, such as (Alraimi \& Abdalla, 2019), magazine e.g. (Bankole \& Ayoola, 2014), speech e.g. (Feng \& Liu, 2010; Taping et al., 2017), magazine, such as (Bankole \& Ayoola, 2014), speech, such as (Hadiani, 2019). In contrast to the previous study, Hadiani (2019) focused primarily on explanation text in his interpersonal meaning analysis of academic material. Meanwhile, another type of academic text received less attention. As a result, the analytical exposition text becomes an important text to evaluate as a scientific text that discusses phenomena around us from a point of view in depth and critically.

As a result, the purpose of this study is to look into how students in the English Department realize interpersonal meaning when producing analytical exposition texts. They should be able to change, modify, compromise, constrain, or contest the essence of a statement from its own point of view. Analytical exposition text is an important element to examine, particularly for English Department students, because it has the function of persuading people to see things from their point of view. This type of text will be used 
regularly by them not only as a text but also in the creation of letters, essays, and newspaper articles with the goal of persuading the reader. It is stated that students in the English Department must be capable of writing a relevant analytical exposition text. Investigating the interpersonal meaning-making of English Department students who are producing analytical exposition texts will reveal how they adopt a stance in the text and how they interact and relate to the readers.

\section{METHOD}

This study employed a qualitative research approach and a descriptive content analysis as the study's design. The researchers employed a qualitative study design to investigate the text's interpersonal meaning. A qualitative study tries to describe and analyze occurrences, events, social activities, attitudes, beliefs, perceptions, and ideas of individuals or groups of people. Furthermore, descriptive content analysis aims to provide a detailed description of a message or text. It is not meant to be used to test a specific hypothesis or a relationship between variables.

In this study, the source of data is gained by analyzing analytical exposition texts written by English-major students of Universitas Sultan Ageng Tirtayasa at the 5thsemester of academic year 2019/2020. The data was taken by document analysis from 146 participants in the three classes. The procedure used to analyze the data is document analysis. Document analysis is a method of a qualitative study in which the researchers identify the documents to offer voice and sense to the subject of the evaluation (Bowen, 2009). In selecting the data, the writer used a random sampling technique to choose three samples from each class, meaning that there are nine texts to be investigated in this study. All types of clauses and sentences were two elements in the text that had been analyzed.

Miles and Huberman's interactive model of analysis was used to analyze the data (Miles \& Huberman, 1994). The researchers discuss the process of evaluating data by selecting, focusing, reducing, and altering it, starting with data reduction. The document's source is huge and intricate. As a result, data reduction is essential in order to make data more understandable and usable. Then there's data display, which is a well-organized, compacted collection of data that allows for conclusions to be drawn. We can use data visualization to comprehend what's going on and take action. As a temporary conclusion, the writer begins to decide what things mean, and retains these conclusions lightly; the data triangulation of this research received from the expert to explain the researching interpersonal meaning-making in the text.

\section{RESULTS AND DISCUSSION}

\section{Mood Types}

The result of the investigation revealed that declarative is the most common mood type among students authoring analytical exposition texts. The declarative mood has a higher statistical significance than the other moods. 95.24 percent of people are in a declarative mood. Declarative mood is employed to actualize the statement speech 
function. It indicates that students prefer to supply a lot of information and that they are making an attempt to provide precise information. This study also includes a common declarative mood type to demonstrate the students' efforts to provide precise information, particularly in saying why smoking is harmful and providing smoking facts. The declarative mood type is used to demonstrate skills in stating information. This is also an attempt to persuade readers that smoking is harmful. Another goal of utilizing a declarative mood like this is to demonstrate their skill in delivering and explaining information to the audience. As a result, the readers will have the same perspective as the authors on the problem. The tables below show the text's stated results.

IM/S1.06
\begin{tabular}{|c|l|l|l|l|l|l|l|l|}
\hline Actually & when & cigarette & Is & smoked, & nicotine & will & Flow & $\begin{array}{l}\text { into the human lungs and } \\
\text { brain which can trigger the } \\
\text { dopamine hormone }\end{array}$ \\
\hline & & & & & Subject & Finite & Predicator & Complement \\
\hline $\begin{array}{c}\text { Adj: } \\
\text { mood }\end{array}$ & Complement & Subject & Finite & Predicator & \multicolumn{3}{|c|}{ Complement } \\
\hline \multicolumn{2}{|c|}{ RESIDUE } & \multicolumn{2}{|c|}{ MOOD } & \multicolumn{3}{c|}{ RESIDUE } \\
\hline
\end{tabular}

IM.S3/07
\begin{tabular}{|l|l|l|l|l|l|l|}
\hline Smoking & can & be & Dangerous & for smoker & but & $\begin{array}{l}\text { more dangerous for } \\
\text { people who smoke } \\
\text { the cigarette smoke }\end{array}$ \\
\hline Subject & Finite & Predicator & Complement & $\begin{array}{l}\text { Adj: } \\
\text { Circumstantial }\end{array}$ & Adj: Conjunctive & Complement \\
\hline \multicolumn{2}{|c|}{ MOOD } & \multicolumn{6}{|c|}{ RESIDUE } & RESIDUE \\
\hline
\end{tabular}

Interrogative mood is the second most common mood type, accounting for 3.40 percent of all mood types in the data analysis, or only 5 in total. The interrogative mood type is used to actualize the question speech function. Instead than eliciting a response from the listener, the interrogative mood is used to remind people how to act (Lin, 2011). This indicates that pupils only utilize the interrogative mood type for rhetorical questions. Lin (2011), claims that the use of the interrogative mood is uncommon. However, in this case, the interrogative mood type is utilized at the beginning of the paragraph to draw the reader's attention. This conclusion supports Lin's assertion that the interrogative mood's function isn't always to elicit an answer from the audience.

IM.S3/01

\begin{tabular}{|l|l|l|l|l|l|l|l|l|l|l|}
\hline Have & You & ever & felt & $\begin{array}{l}\text { your } \\
\text { clothe-s }\end{array}$ & Smell & $\begin{array}{l}\text { of } \\
\text { cigarettes }\end{array}$ & because & $\begin{array}{l}\text { People } \\
\text { around } \\
\text { you }\end{array}$ & $\begin{array}{l}\text { Smoke } \\
\text { places more } \\
\text { precisely } \\
\text { like in } \\
\text { public }\end{array}$ \\
\hline
\end{tabular}




\begin{tabular}{|c|c|c|c|c|c|c|c|c|c|c|c|c|}
\hline & & & & & & & & & & & & $\begin{array}{l}\text { vehicles like } \\
\text { bus, ankot, } \\
\text { etc? }\end{array}$ \\
\hline & & & & Subject & $\begin{array}{l}\text { Fini } \\
\text { te }\end{array}$ & $\begin{array}{l}\text { Pred } \\
\text { icato } \\
\text { r }\end{array}$ & $\begin{array}{c}\text { Complem } \\
\text { ent }\end{array}$ & $\begin{array}{l}\text { Adj: } \\
\text { Circmst } \\
\text { antial }\end{array}$ & Subject & $\begin{array}{l}\text { Fini } \\
\text { te }\end{array}$ & $\begin{array}{l}\text { Predica } \\
\text { tor }\end{array}$ & $\begin{array}{l}\text { Adj: } \\
\text { Circumsta } \\
\text { ntial }\end{array}$ \\
\hline & & & & \multicolumn{2}{|c|}{ MOOD } & \multicolumn{2}{|c|}{ RESIDUE } & - & \multicolumn{2}{|c|}{ MOOD } & \multicolumn{2}{|c|}{ RESIDUE } \\
\hline Finite & $\begin{array}{c}\text { Subjec } \\
t\end{array}$ & $\begin{array}{l}\text { Adj: } \\
\text { Mo } \\
\text { od }\end{array}$ & $\begin{array}{c}\text { Predica } \\
\text { tor }\end{array}$ & \multicolumn{9}{|c|}{ Complement } \\
\hline \multicolumn{2}{|c|}{ MOOD } & \multicolumn{11}{|c|}{ RESIDUE } \\
\hline
\end{tabular}

IM.S8/01

\begin{tabular}{|l|l|l|}
\hline Are & You & still wanting to smoking \\
\hline Finite & Subject & Complement \\
\hline & RESIDUE \\
\hline
\end{tabular}

IM.S1/05

\begin{tabular}{|c|c|c|c|c|c|c|c|c|c|}
\hline So & Why & does & people & still & smoking & $\begin{array}{l}\text { even } \\
\text { through }\end{array}$ & It & is & $\begin{array}{l}\text { for their mental } \\
\text { health }\end{array}$ \\
\hline & & & & & & & Subject & Finite & $\begin{array}{l}\text { Adj: } \\
\text { Circumstantial }\end{array}$ \\
\hline & & & & & & & \multicolumn{2}{|c|}{ MOOD } & RESIDUE \\
\hline $\begin{array}{l}\text { Adj: } \\
\text { Conjunctive }\end{array}$ & Complement & Finite & Subject & $\begin{array}{l}\text { Adj: } \\
\text { Mood }\end{array}$ & Predicator & \multicolumn{4}{|c|}{ Complement } \\
\hline- & RESIDUE & \multicolumn{2}{|c|}{ MOOD } & \multicolumn{6}{|c|}{ RESIDUE } \\
\hline
\end{tabular}

Finally, the imperative mood is only employed 1.36 percent of the time, or 2 times in the text. The imperative mood was utilized to realize the command speech feature. The students' commitment to creating analytical exposition texts aligns with its function of providing detailed information, as seen by the low frequency of interrogative mood use. When a predicator appears at the start of a sentence or clause, the imperative mood type can be identified. According to Gerot \& Wignell (1994), the urgent mood type may or may not include a mood element, while the mood type always includes a predictor. They also say that the author has sent an imperative to the listener to do something. The tables below show the imperative findings from the text.

IM.S3/08

\begin{tabular}{|l|l|l|l|l|l|l|l|l|}
\hline Therefore & let's & avoid & smoking & $\begin{array}{l}\text { in public } \\
\text { places }\end{array}$ & And & It & $\begin{array}{l}\text { is } \\
\text { avoid } \\
\text { smoking }\end{array}$ \\
\hline $\begin{array}{l}\text { Adj: } \\
\text { Conjunctive }\end{array}$ & Predicator & Predicator & Complement & $\begin{array}{l}\text { Adj: } \\
\text { Circumstantial }\end{array}$ & $\begin{array}{l}\text { Adj: } \\
\text { Cnjunctive }\end{array}$ & Subject & Finite & Complement \\
\hline- & \multicolumn{9}{|c|}{ RESIDUE } & - & \multicolumn{2}{c|}{ MOOD } & RESIDUE \\
\hline
\end{tabular}


IM.S5/21

\begin{tabular}{|l|l|l|l|}
\hline Just & let & Them & life in freedom \\
\hline Adj: Mood & Predicator & Complement & Complement \\
\hline \multicolumn{3}{|c|}{ RESIDUE } \\
\hline
\end{tabular}

\section{Modality Realization}

The dominant modality employed in the text is median modality, according to the data analysis. It was discovered that 49 of them, or 96.08 percent, appeared in the text. It means that the students persuade the readers to agree with the writer's point of view by demonstrating the topic's possibilities to the writer. Dian \& Ernie (2017), Houfei Yang (2017), Alrami (2019), and Ayoola (2013) all came to the same conclusion. The previous studies found that the dominant modality is the median modality in whatever media they investigated. According to Yang (2017), a writer uses median modality for a variety of reasons: (1) to persuade readers to agree with him/her, (2) to demonstrate his/her commitment to something, (3) to elicit empathy and support from the audience, (4) to communicate intentions and plans, and (5) to demonstrate his/her strong mind and keen desire. The text's median modalities are will and can, based on nine samples in this study. Students utilized median mode to simply express some possibilities of what might happen if the reader smokes, according to the data. Furthermore, students supported their arguments with median modality. The following tables show how students use medium modality will and can modality in their texts.

IM.S5/18

\begin{tabular}{|l|l|l|l|}
\hline Banning the smoking in public & Will & Keep & non-smoker safer \\
\hline Subject & Finite & Predicator & Complement \\
\hline \multicolumn{2}{|c|}{ MOOD } & \multicolumn{2}{c|}{ RESIDUE } \\
\hline
\end{tabular}

IM.S6/17

\begin{tabular}{|l|l|l|l|l|}
\hline $\begin{array}{l}\text { Based on current } \\
\text { smoking patterns }\end{array}$ & $\begin{array}{l}25 \text { million Americans } \\
\text { alive today }\end{array}$ & will & die & $\begin{array}{l}\text { Prematurely from smoking- } \\
\text { related illness }\end{array}$ \\
\hline Complement & Subject & Finite & Predicator & Complement \\
\hline \multicolumn{1}{|c|}{ MOOD } & \multicolumn{2}{|c|}{ RESIDUE } \\
\hline
\end{tabular}

IM.S2/01

\begin{tabular}{|l|l|l|l|l|}
\hline Smoking & can & Lead & you & to death \\
\hline Subject & Finite & Predicator & Complement & Adj: Circumstantial \\
\hline
\end{tabular}

IM.S7/05

\begin{tabular}{|c|c|c|c|}
\hline Smoking & can & cause & various disease \\
\hline Subject & Finite & Predicator & Complement \\
\hline
\end{tabular}

The second most common modality in the text was high modality, which accounted for 3.92 percent of the total, or only two instances. In his study on interpersonal metafunction analysis of Barack Obama's Inaugural address, Hufei Yang (2017) stated that 
the writer and speaker use high modality for three reasons: (1) to show the speaker's strong determination to archive his/her statement, (2) to emphasize their qualities, and (3) to emphasize their readiness and strong trust in something. Students chose to show a strong commitment to suggest that smoking locations in public places such as buses and children's areas be closed, according to IM.S3/03 data.

\begin{tabular}{|c|c|c|c|c|c|c|c|}
\hline In Indonesia & it & is & Strictly & $\begin{array}{l}\text { forbidden to } \\
\text { smoke }\end{array}$ & $\begin{array}{l}\text { in public } \\
\text { places }\end{array}$ & $\begin{array}{l}\text { Such on } \\
\text { airconditioned } \\
\text { buses which } \\
\text { must have been } \\
\text { provided } \\
\text { smoking areas }\end{array}$ & $\begin{array}{l}\text { Also in } \\
\text { places that } \\
\text { are usually } \\
\text { visited by } \\
\text { children } \\
\text { must have } \\
\text { been } \\
\text { prohibited } \\
\text { from } \\
\text { smoking in } \\
\text { that pace }\end{array}$ \\
\hline $\begin{array}{l}\text { Adj: } \\
\text { Circumstantial }\end{array}$ & Subject & Finite & $\begin{array}{l}\text { Adj: } \\
\text { Mood }\end{array}$ & Complement & $\begin{array}{l}\text { Adj: } \\
\text { Circumstantial }\end{array}$ & Complement & Complement \\
\hline
\end{tabular}

Meanwhile, it's worth noting that no single low-modality realization can be found across all data. Low modality realization reveals a shaky impression and uncertainty regarding the text's topic. The pupils' use of low modality also shows that they do not leave room for the reader to doubt their place in the text. It is critical not to leave the listener in any doubt about what the writer is saying in an analytical exposition text.

\section{CONCLUSION}

This study looked at how interpersonal meaning is expressed in students' analytical exposition writing at the University of Sultan Ageng Tirtayasa's English Department. The declarative mood type is the most prevalent mood type in every sample, with 95.4 percent or 140 occurrences, as indicated in the findings and discussion. The structure of the mood element in the subject and finite in the sentence can be used to determine the mood type. The findings of this study demonstrate how interpersonal meaning manifests itself in the text. This conclusion implies that the writer provides a lot of information from the text as a function of analytical exposition text to persuade the reader to share the writer's point of view.

In terms of modality analysis, the median modality dominated the text, accounting for 96.08 percent of all occurrences (49). It implies that the students, as writers, strive to provide accurate information while maintaining an equal relationship with the reader. Finally, students were able to write an effective analytical exposition text that was intended to critically discuss something from one point of view. As a result, teachers must continue to emphasize the teaching and learning process in order to encourage students to devote 
more time to improving their writing skills. As a writing strategy, a problem-solving approach is supposed to develop students' communicative skills. However, more research is needed to provide a more accurate picture of the approach's success.

\section{REFERENCES}

Alraimi, L. M., \& Abdalla, A. Y. (2019). Interpersonal meaning in media texts written by native \& non-native writers of English. International Journal of Linguistics, 11(1), 79. https://doi.org/10.5296/ijl.v11i1.14370

Ayoola, \& Olusanya, M. (2013). An interpersonal metafunction analysis of some selected political advertisements in some Nigerian newspapers. International Journal of Humanities and Social Science, 3(8), 165-178.

Bankole, M, \&Ayoola, M. O. (2014). Mood and modality in Christian Magazines: A systemic functional analysis of christian women mirror. International journal of humanities and social science, 4(14), 138-149.

Bowen, G. A. (2009). Document analysis as a qualitative research method. Qualitative Research Journal, 9, 27-40.

Creswell, J. W. (2009). Research Design: Qualitative, Quantitative, and Mixed Methods Approaches. Newbury Park: Sage Publication.

Creswell, J. W. (2012). Educational Rresearch: Planning, Conducting, and Evaluating Quantitative and Qualitative Research. Boston: Pearson Education, Inc.

Derewianka, B. (2004). Exploring New Text Works. Rozelle: Primary English Teacher Association.

Dornyei, Z. (2007). Research Method in Applied Linguistics. United Kingdom: Oxford University Press.

Eggins, S. (1994). An Introduction to Systemic Functional Linguistics. London: Printer Publisher, Ltd.

Emilia, Emi. (2014). Introducing Functinal Grammar. Pustaka Jaya: Bandung

Feng, H.,\& Liu, Y. (2010). Analysis of interpersonal meaning in public speeches-A case study of Obama's speech. Journal of Language Teaching and Research, 1(6), 825-829. https://doi.org/10.4304/jltr.1.6.825-829

Gerot, L., \& Wignell, P. (1994). Making Sense of Functional Grammar. Gerd Stabler.

Halliday, M. A.K . (1976). System and Function in Language (G. Kress (ed.)). Oxford University Pers.

Halliday, M.A.K. (1985). Spoken and Writen Language. Geelong, Victoria: Deakin University Halliday, M.A.K. (1985). Part A of Language, Context, and Text:Aspects of Language in a Social Semiotic Perspective. Burwood, Melbourne: Deakin University.

Halliday, M. A.K . (1994). An Introduction to Functional Grammar (2nd ed.). Edward Arnold. Halliday, M.A.K. (2002). On Grammar. London: Continuum

Lin, K. H. (2011). An Analysis of Public Speech on the Interpersonal Metafunction of Systemic Functional Linguistics - Three Examles of Barack Obama's Speeches. National Pingtung 
IInstItute of Commerce.

Miles, M. B., \& Huberman, M. (1994). An Expanded Sourcebook: Qualitative Data Analysis. Sage Publications.

Patton, M. Q. (2002). Qualitative Rresearch and Evaluation Methods (3 ${ }^{\text {rd }}$ ed.). Sage P

Sukma, B. P., \& Utomo, D. W. (2016). Interpersonal metadiscourse in the Jakarta Post ENews Opinion Articles. Jurnal BEBASAN Jurnal Ilmiah Kebahasaan dan Kesastraan, 3(1), 17-27.

Taping, M. G., Juniardi, Y., \& Utomo, D. W. (2017). Rhetorical devices in Hillary Clinton concession speech. Journal of English Language Studies, 2(2).

Yang, H. (2017). The interpersonal metafunction analysis of Barack Obamas' inaugural address. International Journal of Languages, Literature, and Lingustics, 3, 27-30.

Yuliana, D., \& Imperiani, E. D. A. (2017). The realization of interpersonal meaning in course newsletters: A systemic functional linguistic perspective. Indonesian Journal of Applied Linguistics, 7(1), 181-188. https://doi.org/10.17509/ijal.v7i1.6873 